\title{
Монгол Улсын Ерөнхийлөгч Цахиагийн ЭЛБЭГДОРЖ-ийн ХБНГУ-д төрийн айлчлал хийх үеэр Германы Бундестагт хэлсэн үг
}

Өнөөдөр ямар сайхан өдөр вэ!

Энэ сайхан өдрийг авч ирэхийн төлөө бидэнтэй хамтран зүтгэсэн Германы ард түмэнд Монголын ард түмний чин сэтгэлийн мэндчилгээг өргөн дэвшүүлье. Энэ өдрийг би удаан хүлээсэн. Та бүхэн бол дарангуйллын ханыг нурааж болдгийг, тайван замаар эрх чөлөөгөө олж болдгийг, хөгжил дэвшлийг хамтдаa бүтээж болдгийг харуулж чадсан гайхалтай хүмүүс. Бид ч энэ замд нэгдэж чадсандаa баяртай байдаг.

Монголчууд зарим ард түмнийг хамгийн урт хана хэрэм босгоход хүргэж байсан. Монголын ард түмэн 1990 оны цагаан морин жил коммунизмын ханыг Германы ард түмний нэгэн адил эх нутагтаа нурааж чадсан. Одоо бид бусад улс орон, ард түмэнд эрх чөлөөгөө олж авах, дарлал доромжлол, хүнд суртлын ханыг нураахад нь туслах, дэмжих хүндтэй үүргийг хэрэгжүүлж байна. Монгол Улс өнөөдөр Олон улсын ардчиллын хамтын нийгэмлэгийг даргалж байгаа юм.

Хүн бүр эрх чөлөөтэй байх ёстой гэдэгт би итгэдэг. Гэвч эрх чөлөөт амьдрал бол амар хялбар зам биш гэдгийг бид мэднэ. "Мориндоо мордоод дэлхийг эзлэх амархан. Мориноосоо буугаад төрийг төвхнүүлэх хэцүү” гэж Чингэс хаан хэлсэн юм. Дэлхийд хоёр дахь социалист улс болж гарч ирсэн тэр системийг өөрчлөхөд эрсдэлтэй, хэцүү байсан. Түүнийг Монголчууд хийж чадсан. Харин шинэ, ардчилсан, шударга нийгмийг бүтээн байгуулах үйл явц өнөөдөр ч гэсэн Монгол улсад хүнд хэцүҮ сорилтуудтай тулгарсаар байна.

Эндээс долоон мянган километрийн алсад Лайпцигийн даваа гаригийн жагсаалуудтай зэрэг шахам, 1989 оны сүүлчээр тэсгим хүйтэн өвөл шинэ хаврыг угтаж өрнөсөн Монголын ардчилсан хөдөлгөөн манай бүс нутагт хосгүй амжилтад хүрснийг энд тэмдэглэе. Монголчууд хуучныг өөрчилж шинийг бүтээх ардчилсан хувьсгалаа тайван замаар нэг ч хүний хацар шалбалахгүйгээр хийж чадсан. Улс төр, эдийн засгийн иж бүрэн өөрчлөлтийг нэгэн зэрэг хийх хэцүү замыг бас сонгосон. Ийм сонголтыг тэр бүр Азийн улс орнууд хийж зүрхлээгүй, бас чадаагүй. Өнөөдөр Монгол Улс Европ тивийн зүүн эргээс Япон тэнгис хүртэлх уудам бүс нутагт сүүлийн 20 гаруй жил төлөвшин тогтсон улс төр, эдийн засаг, иргэний нийгмийн хамгийн чөлөөт тогтолцоог бүтээж чадсан.

ЭнэхүҮ амжилтад хүрэхэд 1990 оны эхээр Европ тивээс бидэнд хамгийн түрүүлж халуун гараа сунгасан орон бол Герман Улс, германы ард түмэн юм. Тэр үед ардчилал, нээлттэй нийгмийн тухай бидний ойлголт асар нимгэн байсан. Ёстой л баруун зүүнээ мэдэхгүй явсан. Тэгэхэд Конрад Аденауер бидэнд ардчиллын хичээлийг А-гаас Я хүртэл заадаг байлаа. Фридрих Эберт иргэний нийгмийн байгууллагуудыг хөл дээр нь дэмжиж босгоход тусалсан. Ханс Зайдел Монголын шинэ Ардчилсан Үндсэн хуулийг боловсруулахаас эхлээд, эрх зүй, шүүхийн шинэтгэлд ханцуй шамлан оролцсон. Германы дээрх аугаа зүтгэлтнүүдийн нэрээр нэрлэсэн сангууд тэр нэрээрээ монголчуудын дунд тусч элэгсэг, зарчимч, дотно герман хүмүүс шиг болтлоо танил ойрхон болсон юм.

ХБНГУ бол Монгол улсад хамгийн их тусламж үзүүлсэн тэргүүлэх хоёр орны нэг. Монголд хандивлагчдын бүлэг үүсгэх санаачилга гаргачдын нэг нь Германы Засгийн газар байсан юм. Том заануудын хооронд эрх чөлөөг эрхэмлэгч цагаан унага хөл дээрээ тэнцэж босоход та бүхний дэмжлэг чухал байсан. Монголд улс төрийн нээлттэй, ардчилсан, эрх зүйт, иргэний шинэ тогтолцоог бүрдүүлэхэд Герман улс хамгийн их хөрөнгө оруулалт хийсэн. Энэ бол манай ард түмний шинэ сонголтын хувьд үнэхээр хосгүй, үнэлж баршгүй тус дэмжлэг болсон юм шүу. Монголчууд хүний тусыг мартдаггүй ард түмэн. 
Өнөөдөр би энэ хүндэт индрээс Германы ард түмний жинхэнэ төлөөлөл болсон та бүхнээр дамжуулан монголын ард түмэн, төрийн нэрийн өмнөөс Монгол түмний шинэ сонголтыг амжилттай хэрэгжүүлэхэд тусалж дэмжсэн, хамтран ажилласан, бас хамтран ажилласаар байгаа ХБНГУ-ын төр засгийн газар, нийт байгууллага, иргэдэд чин сэтгэлийн гүн талархал илэрхийлье. Өнөөдөр надад энэ хүндэт индрээс үг хэлэх боломж олгож байгаа Бундестагийн удирдах зөвлөл, Бундестагийн дэд Ерөнхийлөгч эрхэмсэг ноён Освальд болон Бундестагийн эрхэм гишүүдэд их баярлалаа. Рейхстагийн энэ түүхт ордонд германы ард түмний шууд төлөөлөл болсон та бүхэнтэй уулзаж, ард түмнээ төлөөлөн чин сэтгэлийн үгээ хуваалцаж байгаадаa би баяртай байна.

Эрхэм анд найз нараa!

Монгол, Германы харилцааны түүхийг судлаачид зөвхөн энэ зуунаар биш бүр манай эриний өмнөх цаг хугацаагаар тооцсон байдаг. Бидний өвөг дээдэс Хүннүчүүд Европт ирж Германчуудтай харилцаж байсан түүх бий. Монголын эзэнт гүрний тухай анхны мэдээг Райн хавийн Хайстербахын сүмийн лам (Caesarius) Цэзерус Европчуудад 1222 онд латин хэл дээр нийтлүүлсэн Dialogus miraculorum буюу "Гайхамшгийн тухай ярилцлага" номоороо хүргэсэн байдаг. Үүнээс 20 жилийн дараа Монголчууд Силезийн Легницэд германчуудтай нүYр

тулсан.

Хожим Монголын эзэнт гүрний нийслэл Хархорины төмрийн хүдрийн уурхай, үйлдвэрт Германы мэргэжилтнүүд ажиллаж байсан тухай сурвалж бичигт тэмдэглэсэн байна. Харин өнөө цагт Хархорин хотын туурь, Орхоны хөндийн ариун дагшин газар археологийн малтлагыг Монгол, Германы хамтарсан баг хийж байна. Тэд хоёр орны Ерөнхийлөгч нарын ивээл дор манай нэн эртний түүхийн ул мөрийг тодруулан бэхжүүлж байгаа юм.

2011 оны 10 дугаар сард эрхэмсэг хатагтай Ангела Меркел ХБНГУ-ын Канцлерын хувьд Монгол Улсад анх удаa айлчилсан. Хоёр орны харилцааг шинэ шатанд гаргахад нөлөөлсөн тэр түүхэн айлчлалын үеэр бид олон асуудлыг шийдвэрлэж чадсан. Түүний дотор манай хоёр орон ашигт малтмалыг олборлох, боловсруулах, аж үйлдвэр технологийн салбарт хамтран ажиллах стратегийн түншлэл тогтоож, гэрээ байгуулсан.

Тэр үед Европын санхүүгийн хямрал тойрсон асуудлууд ид оволзож байсан. Холбооны Канцлерын цагаа олсон, маш өндөр агуулгатай айлчлалын үеэр би хатагтай Меркелээс “Бид танд яаж туслах вэ?” гэж асуусан. Канцлер тайвнаар “хамтарч ажиллаж” гэж хариулсан. Бид германчууд та бүхэнтэй хамтран ажиллах гэж ирлээ. Wir sind da, aber mit friedlichen

Absichten.

Монголын тал нутгаас тархах нэгэн мэдээ өнөөдөр дэлхийн сонорыг гайхшруулж байна. Монгол улсын эдийн засаг энэ цаг үед дэлхийд хамгийн хурдтай өсөлттэйд тооцогдож байна. УГ байдал нэлээн урт хугацаанд хадгалагдана гэж судлаачид үзэж байна. Энэ өсөлтийг улс орныхоо хөгжил дэвшил, ард иргэдийнхээ амьжиргааны түвшин, шударга нээлттэй нийгмийнхээ үнэт зүйлстэй хэрхэн уялдуулах нь Монгол Улсын хувьд $\begin{array}{llll}\text { тулгамдсан асудал болоод } & \text { байгаa }\end{array}$

Бид нутаг дээрээ нэмүү өртөг шингэсэн бүтээгдэхүүн үйлдвэрлэхийг хүсч байна. Аль нэг орны эдийн засгийн болон өрөөсгөл ашиг сонирхлын хамааралд хэт автахгүй байхыг эрмэлзэж байна. Мөн байгальд ээлтэй өндөр технологи, тийм үйлдвэрлэлийг Монголдоо нутагшуулахыг хүсч байна. Монгол түмний үндэсний энэ ашиг сонирхолд Герман улстай 
хамтран ажиллах нь цоож түлхүүр адил нийцтэй байна.

Монгол улс өнөөдөр газрын тосны бүтээгдэхүүнээр 100 хувь гаднаас хамааралтай байна. Гэтэл нүүрсний нөөцөөр дэлхийд эхний байруудад орж байна. Миний айлчлалын үеэр нүүрс шингэрүүлэх үйлдвэрийг Монгол улсад барих олон тэрбум еврогийн мега төсөл урагшилна гэдэгт би итгэж байна. Мөн газрын ховор элементийн салбарт хамтран ажиллах яриа хэлцлүүд сонирхогч талуудын хооронд идэвхтэй хийгдэж байна. Бас манай говь нутгийн нар, салхины эрчим хүчийг ашиглах “Gobitec" super төсөл мэргэжилтнүудйн анхаарлыг татаж байна.

Дэд бүтцийн төсөл, түүний дотор Ази, Европыг холбосон төмөр замын дамжин өнгөрүүлэх чадавхийг нэмэгдүүлэх асуудал чухал байна. Зарим усан зам боомт, суваг гарцад гарч болох хүндрэл ч энэ асуудлыг нухацтай авч үзэхийг шаардаж байна. Мөн өндөр технологи, техникийн боловсролын асуудал ч хоёр талын сонирхлыг татаж байна. Энэ бүх салбарт бид Герман улстай хамтран ажиллах нэн сонирхолтой байна. Учир нь бидэнд Германаас болгоомжлох зүйл алга. Герман улсын хөрөнгө оруулалт, өндөр чанар, хариуцлагатай байдал манай улсын ашиг сонирхолд маргаангүй нийцнэ. Бид ийм л харилцан ашигтай хамтын ажиллагааг манай гурав дахь хөршийн бодлого гэж нэрлэж байгаа

Юм.

Эрхэмсэг хатагтай, ноёд о

Монголчууд “танилтай хүн талын чинээ” гэж ярьдаг. Би энэ удаагийн айлчлалаараа ХБНГУ-ын бодлого тодорхойлогч, ажил хэрэгч олон хүнтэй шинээр уулзаж танилцлаа. Түүний дотор Герман Улсын Ерөнхийлөгч эрхэмсэг ноён Иоахим Гауктай дотно танилцсандаа баяртай

байна.

Германы ард түмэн эрх чөлөөнийхөө төлөө тайван хувьсгалаар нэгдэж, нэгдмэл үнэт зүйлтэй болж, хөгжин дэвжиж, хүн төрөлхтний хөгжил дэвшилд их хувь нэмэр оруулж байгаад монголын ард түмэн талархаж байдаг юм. Та бүхний энэ амжилт бол дарлалын гинжнээс салсан, бас салахыг хүсдэг олон олон ард түмэнд үлгэр жишээ болж байгаа. Ерөнхийлөгч Гаук бол тэр үлгэр жишээг өөрийн биеэр үзүүлж яваа ховор хувь заяатай хүн юм. Би энэ хүний урилгаар Монгол Улсын төрийн тэргүүний хувьд Европт, тэр тусмаа элэгсэг дотно Герман Улсад анх удаа төрийн айлчлал хийж байгаадаа туйлын билэгшээж байна. Энэ бол Германы ард түмнээс,төрөөс монголын ард түмний ардчилал, эрх чөлөө, нээлттэй нийгмийн төлөө хийсэн түүхэн сонголт, ололт амжилтад үзүүлж байгаа гүн хүндэтгэл хэмээн бид хүлээн авч байна. Монгол, Германы түүх хамтын ажиллагааны олон билэгдэлт хуудсыг энэхүү айлчлалаараа бид баяжуулж чадна гэдэгт итгэлтэй байна.

Өнгөрсөн жил Монгол улс тулгар төрийнхөө 2220 жил, тусгаар тогтнол эрх чөлөөгөө сэргээн тогтоосныхоо 100 жилийн ойг тэмдэглэсэн. Тэртээ хорьдугаар зууны эхээр хаант Оросын армид хүчин зүтгэж явсан Барон фон Унгерн-Штернберг гэдэг нэгэн герман гаралтай офицер Монгол улсыг харийн түрэмгийлэгчдийн дарлалаас чөлөөлөхөд манай эх орончидтой мөр зэрэгцэн тэмцсэн байдаг. Тэрээр Монголын хааныг хаан ширээнд нь эргүүлэн залахад шийдвэрлэх үүрэгтэй оролцсоныхоо төлөө манай сүүлчийн эзэн хааны хамгийн дээд соёрхлыг хүртсэн.

Түүхэн тэр эгзэгтэй үед Монголын төр олон залуусаа Герман улсад эрдэм сургахаар илгээсэн. Тэд шинэ, сэрсэн Монголын оюун санааны алдартай төлөөлөгчид болцгоосон юм. Энэ сайхан уламжлал бүтэн зуунаар тасраагүй үргэлжилсээр өнөөгийн байдлаар 
Монголын 30 гаруй мянган иргэн Герман улсад боловсрол эзэмшсэн байна. Германаар ярьдаг нэг хүнд ноогдох иргэдийнхээ тоогоор Монгол улс дэлхийд дээгүүрт ордог. Энэ бол манай хоёр орны олон жилийн харилцааны хамгийн үнэт баялаг байж болох юм. Бид энэ сайхан уламжлалыг Монгол эх орондоо үргэлжлүүлэхийн тулд Улаанбаатар хотод Монгол-Германы хамтарсан техникийн их сургууль байгуулахаар ажиллаж байна.

Монгол, Германы хамтын ажиллагаа зөвхөн иргэний төдийгүй цэрэг аюулгүй байдлын салбарт ч идэвхтэй өрнөж байна. Монголчууд эх орныхоо нэрийн өмнөөс алба хааж байгаа дайчиддаа гүн хүндэтгэлтэй ханддаг ард түмэн. Сүүлийн 10 жилийн хугацаанд Монголын 6000 шахам цэрэг офицерууд дэлхийн халуун цэгүүдэд энхийг сахиулах 14 ажиллагаанд хамрагдсан. Монгол Улс НҮБ-ын энхийг сахиулах үйл ажиллагаанд идэвхтэй оролцдог дэлхийн 20 тэргүүлэх орны тоонд багтдаг юм.

Цэргийн дүрэмт хувцсаар жигдэрсэн манай зоригт охид, хөвгүүд өнөөдөр ч олон газар алба хааж байна. Тэр дотроо Герман улсын Бундесверийн дайчидтай мөр зэрэгцэн Афганистаны хойт бүсийн командлалын бүтцэд үүргээ нэр төртэй гүйцэтгэж байна. Амь өрссөн нөхцөлд Герман, Монгол цэргүүд бие биеэ таньж, бие биеийнхээ итгэлийг олж баазаасаа гадуур хамтран эргүүл хамгаалалтыг хийж байна. Энэ бол манай хоёр ард түмний бие биедээ итгэсэн итгэлцлийн дээд хэлбэр юм.

Сүүлийн хорь гаруй жилийн эрчимтэй харилцааны үр дүнд манай хоёр улс зөвхөн ижил үнэмлэмжтэй, нэгдсэн ашиг сонирхолтой болсон төдийгүй, түүнийхээ төлөө хамтдаа зогсож, бас хамтдаа ажиллаж чаддаг боллоо. Би нэгдсэн ашиг сонирхол гэж манай энхийг сахиулагчид хамтран хамгаалж байгаа тэр ашиг сонирхлыг хэлж байгаа юм. Эрх чөлөөтэй, шударга, нээлттэй нийгмийг байгуулахын төлөөх манай хоёр ард түмний хамтын хичээл зүтгэлийг би хэлж байгаа юм. Олон улсын тавцанд манай хоёр улс бие биеийнхээ санаачилга, хүчин чармайлтыг харилцан дэмжин ажиллаж байгааг би хэлж байгаа юм. Иймээс Монгол Улс ХБНГУ-тай иж бүрэн түншлэлийн харилцаагаа өргөжүүлэн гүнзгийрүүлж улмаар стратегийн түншлэлийг тогтоох сонирхолтой байна.

Манай хоёр ард түмэнд эрх чөлөөний нийтлэг үнэлэмж амар замаар олдоогүйг би мэднэ. Би хувьдаа жижиг үндэстэн, хүн гэж үгүй гэж боддог. Харин эрх чөлөөгүй хүн, дарлагдсан ард түмэн бол бий. Бид тэдэнд туслах үүрэгтэй. Учир нь хүн бүр эрх чөлөөтэй байх эрхтэй, боломжтой юм. Сүүлчийн хүн эрх чөлөөгөө олох хүртэл өнөөдөр эрх чөлөөтэй байгаа хүмүүс тэр хүний тухай бодож, боломжоороо түүнд туслах ёстой. Эрх чөлөөтэй хүн эрх чөлөөгүй хүний зовлонг ойлгохгүй гэдэг худлаа. Харин түүнийг ойлгодог байх нь, түүнд туслах нь бидний хүн ёсны

Би эрх чөлөөг сүүдрээ нуудаггүй тогтолцоо гэж боддог. Эрх чөлөөнд л хүн сул талаа сайжруулах, суралцах боломж байдаг гэдэгт би итгэдэг. Эрх чөлөөтэй хүн л хүн болж төрснийхөө гавъяаг бүрэн гаргах боломжтой юм. Иймээс хүний мөн чанар, нэр төр, тэр аугаа боломжийг төр тасалдуулах ёсгүй гэж би үздэг. Монголын төрийн түүхэнд хүн цаазлахаас татгалзсан анхны төрийн тэргүүн байгаагаа би энэ бол миний хийх ёстой ажил гэж боддог. Төр нь ямар ч тохиолдолд иргэнийхээ амийг егүүтгэхгүй байх нь шударга, хүнлэг, ёс суртахуунтай төрийн дээд хэмжүүр гэж би үздэг. Энэ бол иргэнийхээ, хүний үнэлэмжийг дээдэлсэн төрийн зайлшгүй хийх ажил юм. 
төрдөө итгэхгүй байгаa учраас төр, иргэний итгэлцэл сулдаж байгаa юм биш. Харин иргэдийн мэдээлэл авах боломж нэмэгдэхийн хирээр төрд тавих шаардлага улам бүр өндөрсөөд, тэр шалгалтад төр тааруу дүн аваад байгаад л учир байна. Өнөөдөр төр улсыг гаднаас нь эзэлж доройтуулахаас илүүтэй төрийн урагшгүй түшмэдүүд шударга бус үйлдлээрээ улс орноо дотроос нь доройтуулах нь олонтоо боллоо.

Төрийн шударга бус байдлыг иргэд нь баян ч бай, ядуу ч бай ямар ч оронд ялгаагүй үзэн ядаж байна шүу дээ. Төрийн эрх ямба гаарсан, иргэдийнхээ эрх оролцоог үгүйсгэсэн, авлига хүнд сурталд идэгдсэн газар бүрээс нийгмийн сайн сайхан, хөгжил дэвшил зугатаж байгааг бид харж байна. Тийм улс орнуудад иргэд нь нээлттэй, шударга, эрх чөлөөт $\begin{array}{lllll}\text { байдлыг нардах нь нэгдж } & \text { шайна. }\end{array}$

Иргэддээ эрхийн шилжилт хийж, хуулийн хэрэгжилт, үйлчилгээндээ төр илүүтэй анхаарах шаардлагатай нь харагдаж байна. Төрийн ажил бол амаргүй ажил. Төрд ажиллана гэдэг бол иргэдийнхээ зовлонг үүрч өөрийн жаргалыг хойш тавина гэсэн үг. Үүнийг би шударга ёстой холбож хардаг. Шударга ёс бол үгээр биш үйлдлээр хэмжигддэг. Гүйцэтгэл шаарддаг. Аль ч оронд төр нь иргэдийнхээ нийтлэг эрх ашигт шударгаар үйлчлэх

ҮҮрэгтэй.

Нийгмийн олон асуудлыг шинэ үнэлэмж, шинэ үе, иргэдийн оролцоогүйгээр шийдэх боломжгүй болж байна. Иймээс Монгол улс Ардчилсан орнуудын хамтын нийгэмлэгийг даргалах хугацаандаа ардчиллын боловсрол, авлигыг үл тэвчих, иргэний оролцоог нэмэгдүүлэх санал санаачилгыг дэвшүүлж түүний хэрэгжилтийн төлөө тууштай хөөцөлдөж байгаа юм. Монгол улс бүс нутагтаа нээлттэй, шударга, сайн засаглалын үлгэр жишээ байхын төлөө хичээж байна. Төрийн авлигажсан муу тогтолцоотой оронд эдийн засгийн өсөлт, их мөнгө сайн зүйл авч ирэхгүй гэдгийг бид сэтгэл зовнин хэлэлцэж байна.

Монголын ирээдүй монгол хүний гарт байгаа гэдэгт би итгэдэг. Монголын хувь заяаг дарга нар нь биш, иргэд нь тодорхойлох замыг бид сонгосон. Иргэдийнхээ нийтлэг хүсэл зоригийг удирдамжаа болгосон, хуулийн алагчлал үгүй хэрэгжилттэй, нээлттэй нийгэмд, тийм улс оронд их ирээдүй бий. Ийм ирээдүйг цогцлоох итгэлт түншээрээ бид Герман анд нөхдөө сонгож байна. Учир нь бидний нөхөрлөл танигдсан, бие биеэ хүндэтгэсэн, үнэнч нөхөрлөл юм. Ийм нөхөрлөл удаан хугацаанд тогтвортой үргэлжилнэ гэдэгт би эргэлзэхгүй

байна.

Анхаарал тавьсанд баярлалаа. 